\title{
SCIENTIFIC PATH OF VIKTOR BORISOVICH SOCHAVA AND HIS CONTRIBUTIONS FOR LANDSCAPE ANALYSIS
}

\author{
Valerian A. SNYTKO \\ Alexey V. SOBISEVICH
}

\begin{abstract}
This paper is dedicated to the life of the Soviet geographer Viktor Borisovich Sochava (1905-1978), who contributed substantially to the geosystemic theory formation in the field of knowledge of Geography, Ecology, and Geosciences in general. The paper covers his academic trajectory and scientific production, pointing out V. Sochava's main research and contributions for landscape analysis and evolution and development of these disciplines in theoretical and applied sciences. The main results of V. Sochava's research are also presented throughout the text.

Keywords: Geosystems; Landscape analysis; Russian Geography.

\section{RESUMO}

TRAJETÓRIA CIENTÍFICA DE VIKTOR BORISOVICH SOCHAVA E SUAS CONTRIBUIÇÕES PARA A ANÁLISE DA PAISAGEM. Artigo dedicado à vida do geógrafo soviético Viktor Borisovich Sochava (1905-1978), que deu uma grande contribuição para a formação da teoria geossistêmica no campo do conhecimento da Geografia, Ecologia e Geociências em geral. O artigo aborda sua trajetória acadêmica e produção científica, apontando as principais pesquisas e contribuições de V. Sochava para a análise da paisagem, a evolução da paisagem e o desenvolvimento dessas disciplinas em ciências teóricas e aplicadas. Os principais resultados das pesquisas de V. Sochava também são apresentados no artigo.
\end{abstract}

Palavras-chaves: Geossistemas; Análise da paisagem; Geografia russa.

\section{INTRODUCTION}

Viktor Borisovich Sochava (Fig. 1) was born on June 7, 1905 in the village of Pargolovo near St. Petersburg. In 1921 he entered the Petrograd Agricultural Institute, where he began his scientific work under the direction of a famous geobotanist and geographer, Vladimir Nikolaevich Sukachev (1880-1967). In 1925, after graduating from the Leningrad Agricultural Institute, V. Sochava was appointed assistant to the Department of Ecology and Plant Geography of this Institute.

In 1926 he started working as an intern at the Botanical Museum of the USSR Academy of Sciences, which was transformed into the Botanical Institute in 1931. For almost 30 years V. Sochava worked here first as a researcher, and then from 1950 to 1964 he was in charge of the Geography and Vegetation Cartography sector. From 1931 to 1936 he combined his work at the Botanical Institute of

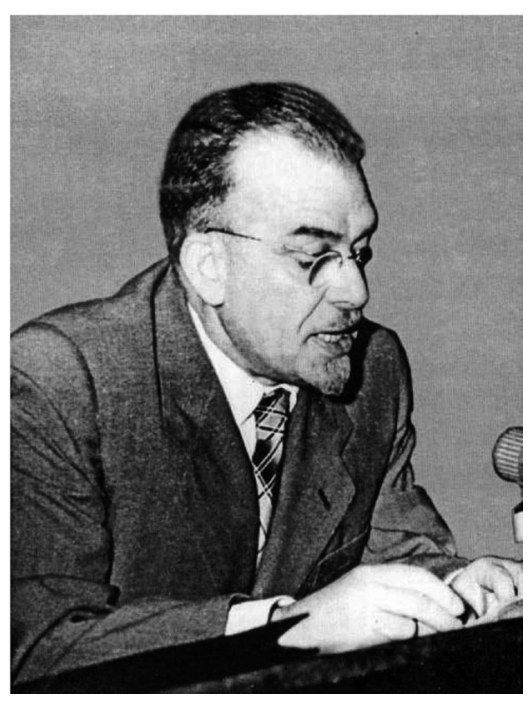

FIGURE 1 - Viktor Sochava making presentation at the conference of the All-Union Botanic Society, 1955 (VOROBIEV et al. 2001). 
the USSR Academy of Sciences with simultaneous work at the Institute of Reindeer Husbandry of the All-Union Academy of Agricultural Sciences of the Soviet Union. From 1936 to 1943 V. Sochava worked at the Arctic Institute and simultaneously taught at the Leningrad State University. After the creation of the Siberian Branch of the USSR Academy of Sciences, Sochava organized the Institute of Geography of Siberia and the Far East in Irkutsk (which was since 1983 named as Institute of Geography of the Siberian Branch of the USSR Academy of Sciences), and was the head of it from 1959 to 1976. Here V. Sochava established a scientific school, which was named Siberian Geographical School.

Candidate of Biological Sciences degree, he was awarded in 1935 for a series of published scientific works in the field of geobotany, even without a thesis defence. In 1943, as a result of his successful defence of his thesis "Geography and cenology of the plant cover of the Amur and Primorye regions", he received the degree of Doctor of Biological Sciences. In 1944, he was approved for the academic title of Professor of Physical Geography. In 1958, V. Sochava was elected a corresponding member, and in 1968 he became an academician of the USSR Academy of Sciences, specializing in Geography.

\section{EXPEDITIONARY ACTIVITIES}

The expedition work of V. Sochava was largely due to the example he took from the famous botanist Vladimir Leontievich Komarov (18691945) in his research of the vegetation of the Far East. The article "A Brief Program of Botanical and Geographical Research in the Amur Region" published by V. Komarov in 1895 greatly helped V. Sochava to organize his own expeditionary work (KOMAROV 1895).

In 1929, V. Sochava was sent by the Polar Commission of the USSR Academy of Sciences to the Anadyr region, where he studied the plant cover of the tundra landscape as a forage reserve for reindeer herding. In 1931-1938, the scientist assessed tundra pastures as the head of the geobotany and fodder sectors at the Institute of Reindeer Husbandry.

In 1932, V. Sochava studied the Anabar tundras. On the basis of expedition research on the tundras of the Anabar basin, he developed a classification of plant associations and their grouping into phytocenosis lists, which were determined by the tundra soil moisture regime. After studying undergoltsy woodland and mountain tundra shrubs, he discovered the process of plant communities layers onlap.

On the basis of expedition research on the tundras of the Anabar basin, V. Sochava developed a classification of vegetation and its grouping into phytocenotic rows, determined by the regime of moisture in tundra soils. By studying undergoltsy woodland and mountain tundra shrubs, he created an idea of the layers of plant communities.

In 1933-1938, V. Sochava edited the series of "Soviet Reindeer Husbandry" journal issues, which he initiated. In the same period, another series of field and theoretical studies by V. Sochawa related to the study of the south of the Far East - the Bureya Range (1931), the Bajal Range and northern SikhoteAlin (1934). Expeditionary research provided him with material for the development of a wide range of geographic and geobotanical problems: the origin and age of high-mountainous flora, relationships between plant communities of Far Eastern forests and their dynamics, the origin of "Ayan" and "Manchurian" types of flora and plant cover with atmospheric circulation.

In 1939, V. Sochava studied modern and ancient glaciation in the highlands of the southwestern part of the Altai, and in 1943-1944 he conducted research in the Middle Urals, where he discovered fragments of the mountain steppe and revealed the relationship between the forest and the steppe with the development of relief. During World War II, when Germany attacked the Soviet Union, V. Sochava explored the southern areas of the European part of the USSR. In 1945-1946, he led the geobotanical unit of the Integrated Expedition of the USSR Academy of Sciences in the North Caucasus. In the course of his research, V. Sochava found that logging in the foothills of forests without taking into account their water conservation and soil protection role could lead to soil erosion.

In 1947-1948, on behalf of the Botanical Institute of the USSR Academy of Sciences, V. Sochava studied forests in Adjara region. In the following years, he led expeditions of the USSR Academy of Sciences in Moldova (1949-1950) and Transcarpathia (1949-1953) to identify opportunities for tea trees cultivation.

In 1960-70, the scientist supervised expeditions of the Institute of Geography of Siberia and the Far East of the Siberian Branch of the USSR Academy of Sciences. A turning point in the development of integrated geographic research methods was the creation of a network of physical and geographical 
observation stations, first in the Onon-Argun steppe (Fig. 2) and then in the taiga zone in the drainage basin of Angara, Ob, Irtysh and Minusinsk Hollow.

\section{CONTRIBUTIONS FOR LANDSCAPE ANALYSIS}

V. Sochava first announced the topic of the landscape theory in 1945, during his presentation at the Geobotany Department of the Botanical Institute of the USSR Academy of Sciences. His work in this field was facilitated by his work at the Department of Physical Geography of the Leningrad University (since 1950), where the oldest landscape and geography school was situated, created by Lev Semyonovich Berg (1876-1950). The creation of the Institute of Geography of Siberia and the Far East opened for Viktor Sochava not only the prospects of using the existing ideas of L. Berg scientific school, but also the further independent development of principles and methods of landscape research, on the basis of which the Siberian Landscape and Geography School was born. The scientific school was formed during the creation of physical and geographical observation stations, which studied the functioning and dynamics of geographic complexes and their natural regimes. For this purpose, V. Sochava developed a special method of complex ordination, i.e. synchronous complex observations over the components of geosystems in different facia and a related study of series of facies. The essence of this method is that natural regimes are synchronously studied at natural polygons, where natural combinations in the areas are identified (VOROBIEV et al. 2001).

V. Sochava described the new direction of landscape research as structural and dynamic. In 1963, he proposed that the objects of such research should be called geosystems. Special attention was paid to the development of various theoretical questions concerning typical geosystems. In order to generalize the dynamic state of geosystems, V. Sochava proposed the term «epifacia».

By involving the systems approach in geographic research, Sochava developed his geosystems theory based on his developments (Fig. $3)$. This was reflected in the monographs "Southern Taiga of the Priangarie region" (SOCHAVA 1969), "Topology of steppe geosystems" (SOCHAVA 1970) and "Topological Aspects of Geosystems Theory” (SOCHAVA 1974). V. Sochava's landscape and geographical concept is described in the most complete form in his monograph "Introduction to the Geosystems Theory" (SOCHAVA 1978).

Geobotanic issues have an important place in the scientific heritage of V. Sochava. He participated in compiling reports on taiga vegetation published in 1953 and 1956. In his early works, he approached the history of vegetation, observing florogenesis and phytocenogenesis as a single process. His

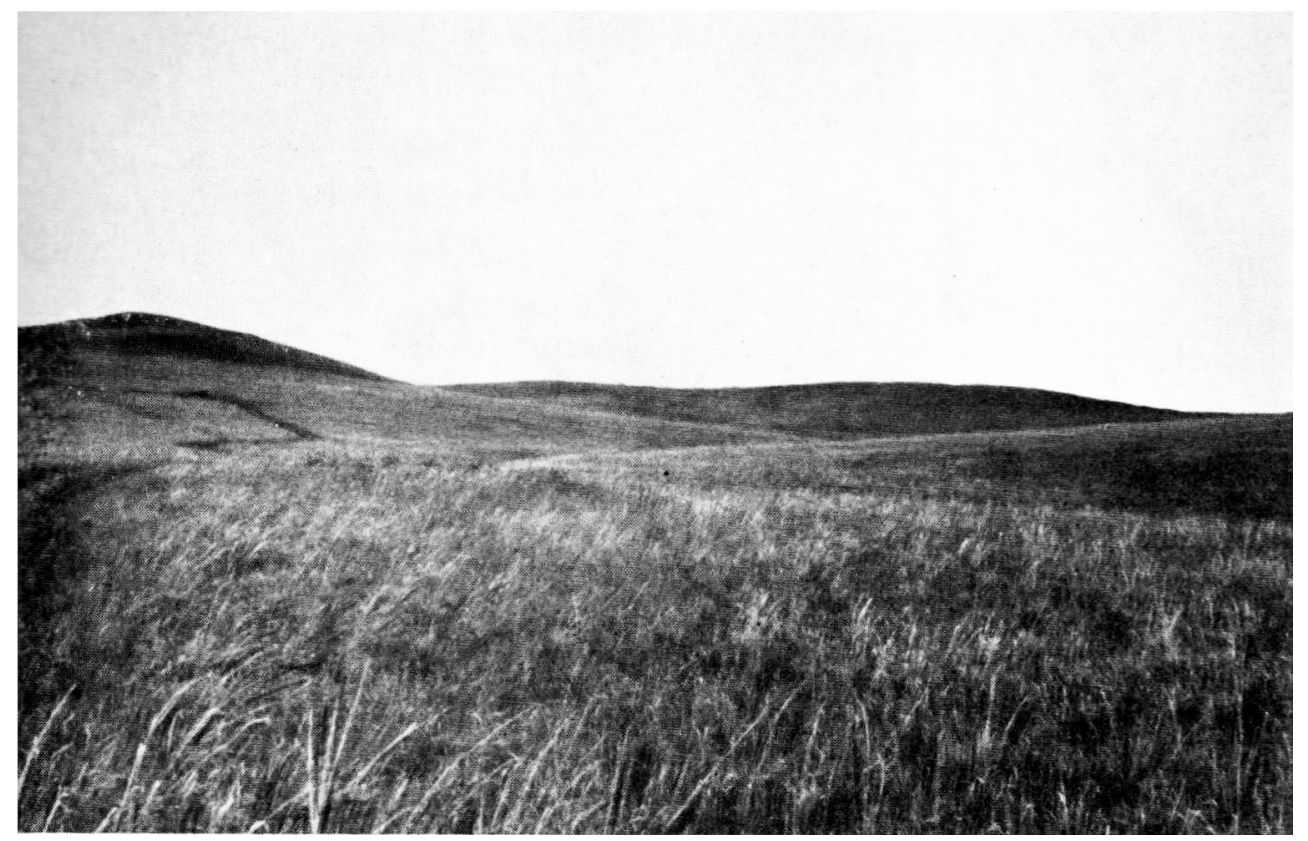

FIGURE 2 - View on the territory of Onon-Argun steppe. Photo by V. Sochava (SOCHAVA 1964). 
main idea in the field of florogenesis was that the development of the organic world is closely linked to the history of landscapes. He reveals the path of vegetation development against the background of paleogeographic reconstructions, including the history of epirogenic movements and atmospheric circulation.

Geobotanic mapping should be separately highlighted in the scientific heritage of V. Sochava. Together with the famous botanist Evgenij Mihailovich Lavrenko (1900-1987), he supervised the development of the "Vegetation Map of the European Part of the USSR" (1950) and the "Geobotanical Map of the USSR" (1954). Founded by V. Sochava in 1963, the yearbook "Geobotanical Mapping" was the only publication of its kind in

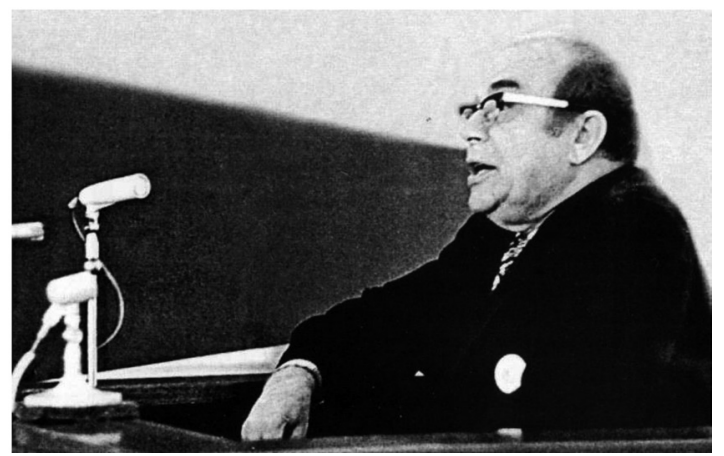

FIGURE 3 - Viktor Sochava's speech at a symposium on the topology of geosystems in Irkutsk, 1971 (VOROBIEV et al. 2001). the world literature. He summarized his ideas in the field with principles and methods of vegetation mapping in the form of the monograph "Plant cover on thematic maps" (SOCHAVA 1979).

In 1970, V. Sochava turned his attention to ecological issues in the Soviet Union. At the $5^{\text {th }}$ Congress of the Geographical Society of the USSR he made a presentation "Geography and Ecology", where he talked about ecological approaches to geosystems modeling. According to his views the most advanced geosystems modeling was made abroad USSR by George M. Van Dyne (1933-1981) at desert-steep territories of Colorado. The advanced studies of different aspects of environment that influence human health were made in Cambridge University, where the Department of Human Ecology was established. The importance of ecological research according to V. Sochava was connected to many problems of humans' adaptation to the fast environmental changes, so geographers had to prevent the undesirable transformation of nature (SOBISEVICH et al. 2019).

\section{ESTABLISHMENT OF SIBERIAN OBSERVATION STATIONS}

Research by the Institute of Geography of Siberia and the Far East, conducted in observation stations, first began in 1958 in the Onon-Argun steppe (Fig. 4) at South-Eastern Trans-Baikal region. The aim of the studies of steppe lands was to study

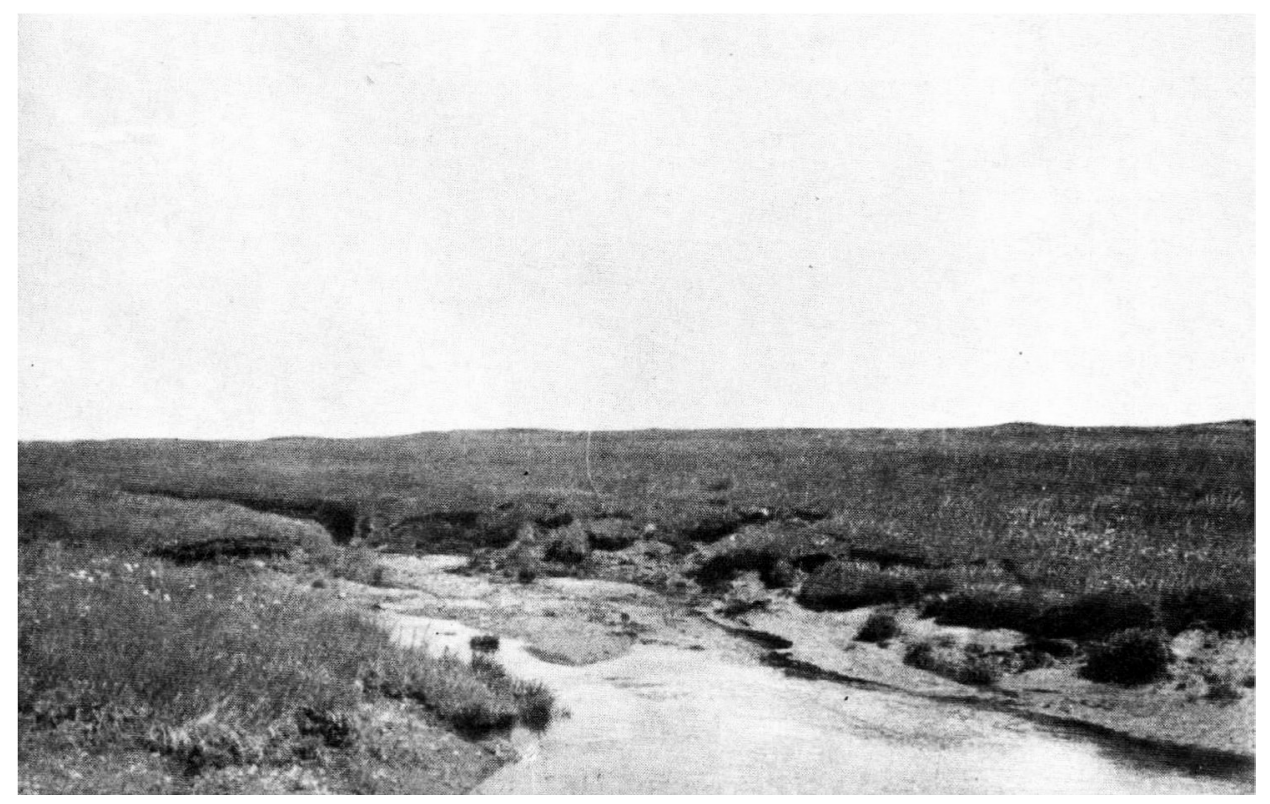

FIGURE 4 - Temporary water course at Onon-Argun steppe. Photo made by V. Sochava (SOCHAVA 1964). 
the rhythms of natural phenomena and justify the division of the territory into special areas called physical-geographical facies. V. Sochava believed that this region is unique because it is one of the types of Asian steppe landscapes penetrated into the taiga zone (SOCHAVA 1964).

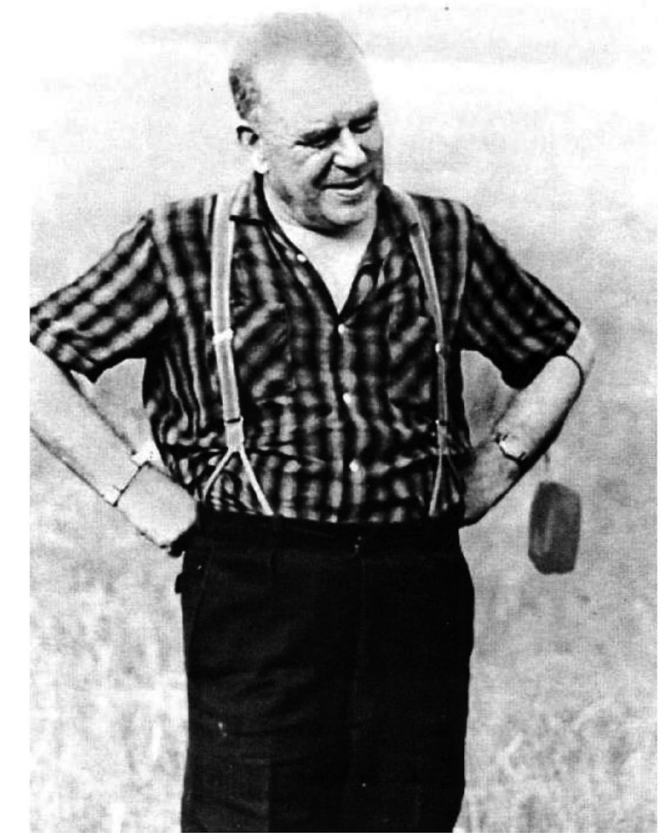

FIGURE 5 - Viktor Sochava at Haranor station, 1967 (VOROBIEV et al. 2001).
The first Siberian geographical observation station - in the Haranorsky steppe - was organized by V. Sochava (Fig. 5, 6) on the basis of an existing biological observation station of the East Siberian branch of the USSR Academy of Sciences in the Alkuchansky Govin tract group. Work at the station was carried out in 1958-1960, and since 1961 it was moved close to the Haranor station of the Trans-Baikal Railway.

The first Priangarsky taiga observation station was established in 1962 near the present Chunoyar railway station on the Trans-Siberian Railway in the Krasnoyarsk - Tayshet section. The purpose of the station was to study the factors that contributed to the formation of the landscape. The studies found that one of the main mechanisms for changing the topography of the Earth's surface in the South-Siberian landscape of Central Siberia is the movement of soils that has hydrothermal nature (KRAUKLIS 1967, SOCHAVA \& KRAUKLIS 1964).

In 1970, V. Sochava began developing a programme to preserve reference samples of taiga nature, for which purpose the Lena Forest Observation Station is being set up in the foothills of the Western Sayan. At the same time, the Novonikolaevskiy Observation Station (Fig. 7) in the steppe zone of the South Minusinsk Basin began to function. It was created to study the migration of

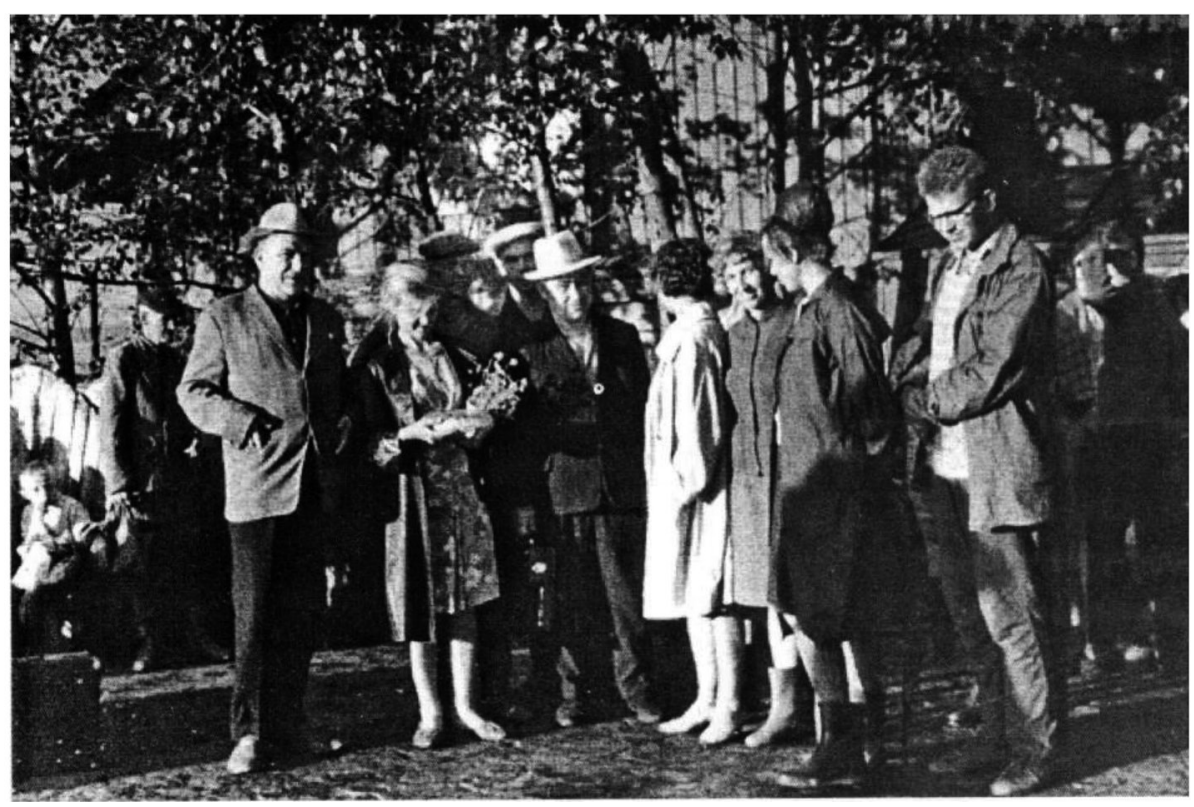

FIGURE 6 - V. Sochava (left) and V. Snytko (right) with their colleagues at Haranor station (VOROBIEV et al. 2001). 


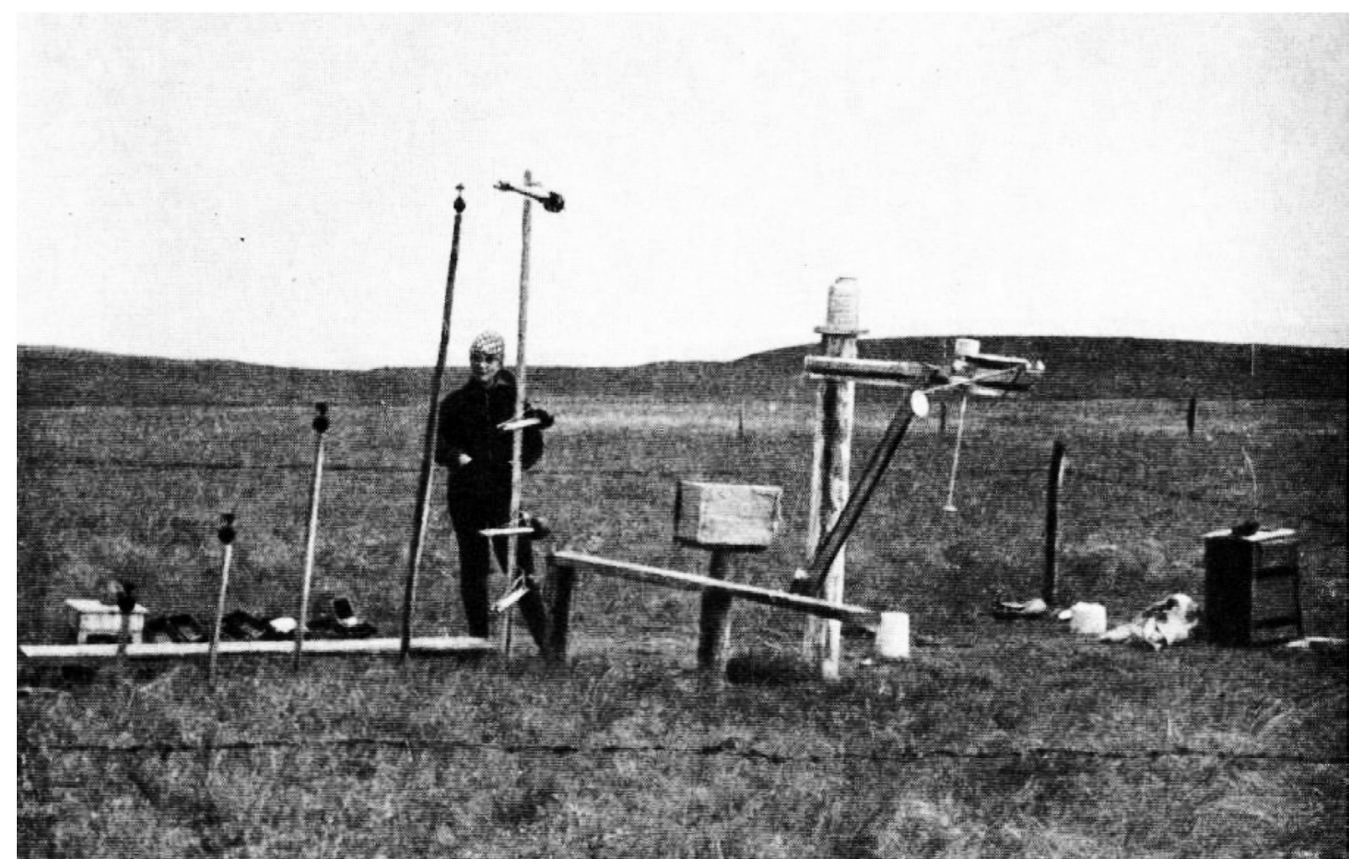

FIGURE 7 - Heat balance monitoring equipment at steppe station. Photo made by V. Sochava (SOCHAVA 1964).

material and energy in zonal steppe geosystems of greatest economic value in the face of increasing anthropogenic impact on natural complexes in South Siberia. Both observation stations became reference points for studies conducted by the South Siberian Geographic Station (SOCHAVA et al. 1973).

\section{CONCLUSION}

V. Sochava's research has always been characterized by a desire not only to reflect the current state of the natural environment, but also to anticipate its future. This was particularly evident in the 1960s and 1970s, when geography was faced with the task of optimising the natural environment. He was one of the first scientists in Soviet Union, who in 1956 raised the issue of geographic forecasting. The main theoretical prerequisites for the development of geographic forecasts he formulated in the books "Introduction to Geosystems Theory" and "Geographic Aspects of the Siberian Taiga" (SOCHAVA 1978, 1980).

Sochava strongly believed in the enormous potential of geographical science, and he saw in the geosystems theory a theoretical basis for solving the most acute problems of optimising the natural environment. He used his ideas in applied geography to solve acute problems in the development of taiga. At present, his research and development is used to solve problems in the development of Siberian territories.

V. Sochava made a significant contribution for geosystems, when he established the relationship between various components of natural environment and established the laws, which underlying the integration of natural regimes. The development of these issues is considered to give great benefits to the rational use and reproduction of natural resources.

\section{ACKNOWLEDGEMENTS}

The research was carried out with the support of the Russian Science Foundation (RSF) according to the scientific project № 20-78-10095 «Soviet science as an industry: personnel, infrastructure, organizational and management practices (19201970s). The authors thank the reviewer for the valuable suggestions.

\section{REFERENCES}

KOMAROV, V.L. 1895. Brief program of botanical and geographical research in the Amur region (for 2 years: 1895 and 1896). Izvestiia Russkogo geograficheskogo obshchestva 
[Bulletin of the Russian Geographical Society], 31(2): 1-17 (in Russian).

KRAUKLIS, A.A. 1967. Experience of stationary research of landscape structure (on the example of the Lower Angara region). Vestnik instituta geografii Sibiri i Dal'nego Vostoka [Reports of the Institute of Geography of Siberia and the Far East], 16: 32-41 (in Russian).

SOBISEVICH, A.V.; SNYTKO, V.A.; POSTNIKOV, A.V. 2019. The surrounding environment monitoring in the Soviet Union: A review of establishing new ecological science. IOP Conference Series: Earth and Environmental Science, 350(1): 1-6.

SOCHAVA, V.B. 1964. Onon-Argunskaya step' kak ob»yekt statsionarnykh fizikogeograficheskikh issledovaniy [Onon-Argun steppe as the object of stationary physical and geographical research]. Alkuchansky Govin. Experience of stationary study of the steppe's landscape. Moscow, p. 3-23 (in Russian).

SOCHAVA, V.B. 1969. Tayga kak tip prirodnoy sredy [Taiga as a type of natural environment]. In: Southern Taiga of the Priangarie region, Leningrad, Nauka, p. 5-14 (in Russian).

SOCHAVA, V.B. 1970. Topologiya stepnykh geosistem [Topology of steppe geosystems]. Edited by V.B. Sochava, Leningrad, Nauka, 170 p. (in Russian).
SOCHAVA, V.B. 1974. Geotopologiya kak razdel ucheniya o geosistemakh [Geotopologiya as a section of the doctrine of geosystems]. In: Topological Aspects of Geosystems Theory, Novosibirsk, Nauka. p. 3-86 (in Russian).

SOCHAVA V.B. 1978. Introduction to the Geosystems Theory. Novosibirsk, Nauka, 319 p. (in Russian).

SOCHAVA, V.B. 1979. Plant cover on thematic maps. Novosibirsk, 190 p. (in Russian).

SOCHAVA, V.B. 1980. Geographic aspects of the Siberian Taiga. Novosibirsk, $256 \mathrm{p}$. (in Russian).

SOCHAVA, V.B.; KRAUKLIS, A.A. 1964. Landscape research of taiga territories (tasks, methods, prospects). Reports of the Institute of Geography of Siberia and the Far East, 5: 33-37 (in Russian).

SOCHAVA, V.B.; BELOV, A.V.; BOGOIAVLENSKIJ, B.A 1973. The main directions of cartographic support for the development of the economy and the use of resources of Siberia and the Far East. In: Economic and geographical forecasting, Irkutsk, SO RAS publishing house, p. 22-27 (in Russian).

VOROBIEV, V.V.; SNYTKO, V.A.; NECHAEVA, E.G. 2001. Viktor Borisovich Sochava (zhiznennyy put', nauchnoye tvorchestvo) [Viktor Borisovich Sochava (life path, scientific creativity)]. Novosibirsk, SO RAS publishing house, 194 p. (in Russian).

\section{Authors' addresses:}

Valerian A. Snytko - S.I. Vavilov Institute for the History of Science and Technology, Russian Academy of Sciences, Baltiyskaya street 14, 125315 Moscow, Russia. E-mail: vsnytko@yandex.ru

Alexey V. Sobisevich - S.I. Vavilov Institute for the History of Science and Technology, Russian Academy of Sciences, Baltiyskaya street 14, 125315, Moscow, Russia / Russian State University for the Humanities, Miuskaia square 6,125315 Moscow, Russia. E-mail: alexsobis@yandex.ru

Manuscript submitted in 4 November 2020, accepted in 7 December 2020. 